\title{
Oxidation of Methanol by the Yeast, Pichia pastoris, Purification and Properties of the Formaldehyde Dehydrogenase ${ }^{\dagger}$
}

\author{
J. J. Allais, A. Louktibi and J. Baratti* \\ Université de Provence, Centre National de la Recherche \\ Scientifique, Laboratoire de Chimie Bactérienne, BP 71, \\ 13277 Marseille Cedex 9, France \\ Received November 16, 1982
}

\begin{abstract}
The formaldehyde dehydrogenase (EC 1.2.1.1) from the yeast Pichia pastoris IFP 206 was purified to homogeneity. The enzyme had a molecular weight of 84,000 daltons and was composed of two identical subunits of a molecular weight of 39,000 daltons. The $\mathrm{N}$-terminal end of the subunits is blocked. The protein showed 6,3 free -SH groups per mole and 12,5 in the presence of $\mathrm{NAD}^{+}$. Enzyme stability was increased by addition of glycerol during the purification.

The enzyme activity is $\mathrm{NAD}^{+}$and glutathione dependent. The reaction product is $S$ formylglutathione. The presence of an $S$-formylglutathione hydrolase (EC 3.1.2.12) in the cell free extract was detected. The formaldehyde dehydrogenase showed an optimum $\mathrm{pH}$ of 7.9 and an optimum temperature of $47^{\circ} \mathrm{C}$. The activation energy was $3.2 \mathrm{kcal} / \mathrm{mol}$. The Michaelis constants for $\mathrm{NAD}^{+}$and $S$-hydroxymethyl glutathione were respectively $0.24 \mathrm{~mm}$ and $0.26 \mathrm{~mm}$.
\end{abstract}

The yeast Pichia pastoris IFP 206 is able to grow on methanol as a sole carbon and energy source. The Institut Français du Pétrole has developed a process for Single Cell Protein Production with this strain cultivated at $34^{\circ} \mathrm{C}$ with a yield of $0.42 \mathrm{~g}$ of cells per $\mathrm{g}$ of methanol and a productivity of $3.5 \mathrm{~g}$ cells/liter $\cdot \mathrm{hr}{ }^{1{ }^{1}}$

In the first paper $^{2}{ }^{2}$ we demonstrated that the first step of methanol metabolism by $P$. pastoris IFP 206 is the oxidation to formaldehyde catalyzed by an alcohol oxidase with FAD as coenzyme. The final electron acceptor is oxygen and the hydrogen peroxide formed by the reaction is broken down by a catalase. The alcohol oxidase was purified and the structural and enzymatic properties described. During this work, a formaldehyde dehydrogenase (EC 1.2 1.1), glutathione dependent, and a formate dehydrogenase (EC 1.2.1.2) were detected in cell free extracts.

The present work reports the complete purification of the formaldehyde dehydro- genase of $P$. pastoris IFP 206 and its structural and enzymological properties in relation with the metabolism of methanol.

\section{MATERIALS AND METHODS}

Microorganism. $P$. pastoris IFP 206 was grown in a continuous culture at the Institut Français du Pétrole by $\mathrm{Dr}$ Ballerini. Lyophilized cells were stored at $-15^{\circ} \mathrm{C}$ until used.

Enzyme purification. The formaldehyde dehydrogenase was purified to homogeneity according to published procedures ${ }^{3,4)}$ with minor modifications. In a typical experiment $100 \mathrm{~g}$ of lyophilized cells was suspended in 4 liters of $5 \mathrm{~mm}$ potassium phosphate buffer (KPB), $\mathrm{pH} 7.5$, containing $30 \mathrm{~mm} \beta$-mercaptoethanol and $0.5 \%(\mathrm{v} / \mathrm{v})$ glycerol, and allowed to stand overnight at $4^{\circ} \mathrm{C}$. The cell suspension was then disrupted with a Braun homogenizer under the following conditions: $40 \mathrm{ml}$ of the cell suspension was mixed with $30 \mathrm{~g}$ of glass beads and homogenized for $10 \mathrm{sec}$ at speed one and $30 \mathrm{sec}$ at speed two. Cell debris was eliminated by $20 \mathrm{~min}$ centrifugation at $5,500 \mathrm{rpm}$ (Sorvall RC 2B, GSA rotor). The clear supernatant was adjusted to a

$\dagger$ This work was supported by a grant from the Delegation Générale à la Recherche Scientifique et Technique $\mathrm{n}^{\circ}$ 79.7.0328.

* To whom all correspondence should be addressed. 
final concentration of $1 \%$ streptomycin sulfate and the pellet eliminated.

The dialysed supernatant was then chromatographed on a DEAE-Sephadex (A-50) column $(6.3 \times 52 \mathrm{~cm})$ equilibrated with $5 \mathrm{~mm} \mathrm{KPB}, \mathrm{pH} 7.5$, containing $30 \mathrm{~mm}$ $\beta$-mercaptoethanol and $0.5 \%$ glycerol. The flow rate was $6.5 \mathrm{ml} / \mathrm{hr} \cdot \mathrm{cm}^{2}$. The adsorbed proteins were eluted with a linear gradient of sodium chloride $(2 \times 4.5$ liters), from 0 to $0.4 \mathrm{M}$ in the equilibration buffer. The fractions with formaldehyde dehydrogenase activity which emerged at a sodium chloride concentration of $0.27 \mathrm{M}$ were pooled and concentrated by ultrafiltration. On the same column formate dehydrogenase was eluted at a sodium chloride concentration of $0.18 \mathrm{M}$.

The formaldehyde dehydrogenase pool was then filtrated through a Sephadex G 100 column $(4 \times 108 \mathrm{~cm})$ equilibrated in $5 \mathrm{~mm} \mathrm{KPB}, \mathrm{pH} 7.5$, containing $30 \mathrm{~mm}$ $\beta$-mercaptoethanol and $0.5 \%$ glycerol. The flow rate was $5.9 \mathrm{ml} / \mathrm{hr} \cdot \mathrm{cm}^{2}$. The active fractions were pooled, concentrated by ultrafiltration and pumped (flow rate, $6.7 \mathrm{ml} / \mathrm{hr} \cdot \mathrm{cm}^{2}$ ) through a hydroxyapatite (Bio-Rad Laboratories) column $(2 \times 46 \mathrm{~cm})$ equilibrated in the same buffer. Elution was performed with a linear gradient $(2 \times 450 \mathrm{ml})$ of potassium phosphate, $\mathrm{pH} 7.5$, from 5 to $50 \mathrm{~mm}$. Formaldehyde dehydrogenase was eluted at a phosphate concentration of $24 \mathrm{~mm}$. The active fractions were concentrated and stored at $-15^{\circ} \mathrm{C}$ after

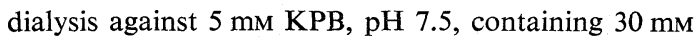
$\beta$-mercaptoethanol and 50\% (v/v) glycerol.

Enzyme activity. The formaldehyde dehydrogenase was assayed spectrophotometrically as described by Van Dijken et al. ${ }^{5)}$ : the incubation mixture contained $2 \mathrm{ml}$ of $150 \mathrm{~mm} \mathrm{KPB}, \mathrm{pH} 7.5$, containing $0.6 \mathrm{~mm} \mathrm{NAD}^{+}$, $\mathrm{xml}$ of enzyme solution, $0.8-\mathrm{xml}$ of water, $0.1 \mathrm{ml}$ of a $90 \mathrm{~mm}$ solution of reduced glutathione and $0.1 \mathrm{ml}$ of a $30 \mathrm{~mm}$ formaldehyde solution. Incubation was done at $37^{\circ} \mathrm{C}$ and the appearance of $\mathrm{NADH}$ was followed spectrophotometrically at $340 \mathrm{~nm}$ (Gilford $2400 \mathrm{spec}-$ trophotometer). Enzyme activity was expressed as micromoles of NADH produced per min and a molar extinction coefficient of $6.22 \times 10^{6} \mathrm{~cm}^{2} / \mathrm{mol}$ was taken for NADH. Usually three assays with different enzyme concentrations were run simultaneously and linear regression was used for the calculation of enzyme activity.
Analytical methods. Proteins were determined by the method of Lowry ${ }^{6)}$ using bovine serum albumin as standard. The concentration of pure enzyme solutions was determined by their absorption at $280 \mathrm{~nm}$ using an extinction coefficient $A_{\mathrm{cm}}^{1 \%}$ of 10.0 determined by ultracentrifugation (see ResULTS). Acrylamide gel electrophoresis, amino acid composition determination, Nterminal determination, free sulfhydryl groups determination and ultracentrifugation analysis were done as already described.2)

\section{RESULTS}

\section{Enzyme purification}

A typical results of formaldehyde dehydrogenase purification are given in Table I. The cell free extract contained $242 \mathrm{mg}$ protein per $\mathrm{g}$ of cell which is lower than the $366 \mathrm{mg} / \mathrm{g}$ previously reported. ${ }^{2}$ This lower protein content was mainly the result of poorer efficiency (60 to $70 \%$ ) of the homogenization step due to the high cell loading. Specific activity was also lower with lyophilized cells $(0.4 \mathrm{U} / \mathrm{mg})$ than with fresh cells $(1.8 \mathrm{U} / \mathrm{mg}){ }^{2)}$ Despite these differences $105 \mathrm{mg}$ of pure formaldehyde dehydrogenase could be obtained from $100 \mathrm{~g}$ of cells with a high purification factor. All the steps were performed in less than 15 days to minimize activity losses. The presence of $30 \mathrm{~mm}$ $\beta$-mercaptoethanol and $0.5 \%$ glycerol in all buffers greatly stabilized the enzyme activity.

The homogeneity of the preparation was checked by polyacrylamide gel electrophoresis. One single band was observed with or without a denaturing agent (see later). The ultracentrifugation pattern showed a single peak and no contaminant $\mathrm{NH}_{2}$ terminal amino acid was detected (see later).

\section{Molecular weight and subunit structure}

The coefficient of sedimentation of the pro-

Table I. Purification of the Formaldehyde Dehydrogenase from $P$. pastoris IFP 206

\begin{tabular}{lrrrrr}
\hline \multicolumn{1}{c}{ Step } & $\begin{array}{c}\text { Total } \\
\text { protein } \\
(\mathrm{mg})\end{array}$ & $\begin{array}{c}\text { Total } \\
\text { activity } \\
\text { (units) }\end{array}$ & $\begin{array}{c}\text { Specific } \\
\text { activity } \\
\text { (units/mg) }\end{array}$ & $\begin{array}{c}\text { Yield } \\
(\%)\end{array}$ & $\begin{array}{c}\text { Purification } \\
\text { factor }\end{array}$ \\
\hline Cell free extract & 24,200 & 10,437 & 0.4 & 100 & 1 \\
Streptomycin sulfate supernatant & 9,120 & 7,490 & 0.8 & 72 & 2 \\
DEAE Sephadex chromatography & 1,010 & 3,906 & 3.9 & 37 & 9 \\
Sephadex G 100 filtration & 364 & 2,240 & 6.1 & 21 & 14 \\
Hydroxyapatite chromatography & 105 & 1,088 & 10.2 & 10 & 24 \\
\hline
\end{tabular}


tein was determined by ultracentrifugation in $5 \mathrm{~mm} \mathrm{KPB}, \mathrm{pH} 7.5$, containing $50 \mathrm{~mm}$ sodium acetate at enzyme concentrations from 0.7 to $2.1 \mathrm{mg} / \mathrm{ml}$. A value of $S_{25, \mathrm{w}}=5.2 \mathrm{~S}$ was calculated and no dependence on the concentration was observed. A partial specific volume of $v=0,765 \mathrm{~cm}^{3} / \mathrm{g}$ was estimated by densitometric determinations of enzyme solutions and used for molecular weight determination by the equilibrium method. A value of 84,000 was found which is in good agreement with the elution volume of the enzyme on gel filtration on Sephadex G-100.

Polyacrylamide gel electrophoresis of our enzyme preparation gave a single peak. No evidence of contamination could be seen. When the experiment was done in the presence of SDS a molecular weight of 39,000 was estimated by comparison with standard proteins. This result compared with the ultracentrifugation experiment strongly suggests that formaldehyde dehydrogenase is composed of two subunits of identical molecular weight.

The ultracentrifugation method of Babul and Stellwagen ${ }^{7)}$ was used to determine the extinction coefficient at $280 \mathrm{~nm}$ of the protein. A value of $A_{\mathrm{cm}}^{1 \%}=10.4$ was estimated from the fringe shift and further used for the estimation of enzyme concentrations.

\section{Structural properties}

The amino acid composition of the enzyme is given in Table II. A large amount of acidic residues $(19 \%)$ are present thus explaining the behaviour of the protein during ion exchange chromatography. From the data in Table II and using the method of Delaage ${ }^{8)}$ a minimal molecular weight of 36,600 was calculated indicating the presence of two identical subunits in the molecule. The molecular weight of the subunits was in good agreement with the determination by SDS gel electrophoresis.

Using the dansylation method no $\mathrm{NH}_{2}-$ terminal was found even after repeating the experiment twice. This lead us to the conclusion that the $\mathrm{NH}_{2}$ terminal amino acid is blocked in the formaldehyde dehydrogenase molecule. The result remained negative at a high protein
Table II. Amino Acid Composition of Formaldehyde Dehydrogenase

\begin{tabular}{cccc}
\hline $\begin{array}{c}\text { Amino } \\
\text { acid }\end{array}$ & $\begin{array}{c}\text { Residues } \\
\text { per mole }\end{array}$ & $\begin{array}{c}\text { Amino } \\
\text { acid }\end{array}$ & $\begin{array}{c}\text { Residues } \\
\text { per mol }\end{array}$ \\
\hline Asp & 66.1 & Met & 7.8 \\
Thr & 40.0 & Ile & 43.8 \\
Ser & 36.1 & Leu & 55.5 \\
Glu & 67.4 & Tyr & 14.1 \\
Pro & 23.8 & Phe & 30.8 \\
Gly & 86.8 & Lys & 62.4 \\
Ala & 53.0 & His & 13.9 \\
Val & 51.4 & Arg & 20.7 \\
Trp & ND & Cys & 12.0 \\
\hline
\end{tabular}

concentration which can be interpreted in terms of the absence of detectable contaminants of a protein nature in our enzyme preparation.

Free sulfhydryl groups were detected and titrated with Ellman reagent. In non-denaturing conditions 6,3-SH groups per mol (MW $78,000)$ were titrated which means that $50 \%$ of the cysteines of the molecule were in the reduced form. In the presence of $1 \% \operatorname{SDS}$ the titrable cysteines were 12.3 which represents the total amount in the molecule. An interesting observation was made in non-denaturing conditions in the presence of $\mathrm{NAD}^{+}(0.6 \mathrm{~mm})$. In these conditions $12.5-\mathrm{SH}$ groups could be titrated per mole of enzyme. Then in the presence of one substrate $\left(\mathrm{NAD}^{+}\right)$all the cysteine residues of the enzyme molecule were titrable with Ellman reagent.

\section{Enzyme stability}

During this work the high instability of the formaldehyde dehydrogenase was noticed even in the presence of $30 \mathrm{~mm} \beta$-mercaptoethanol as proposed by Schütte et al. ${ }^{4}$ The enzyme activity was lost after 7 days storage at $4^{\circ} \mathrm{C}$ as shown in Fig. 1. However much higher stability was obtained in the presence of glycerol which was found to have a dual effect of stabilization against inactivation and restoration of enzyme activity during the first two days of the experiment. Addition of $0.5 \%$ glycerol to the buffers used during the purification lead to a 70 to $80 \%$ recovery of activity in 7 days at $4^{\circ} \mathrm{C}$. A higher glycerol concentra- 


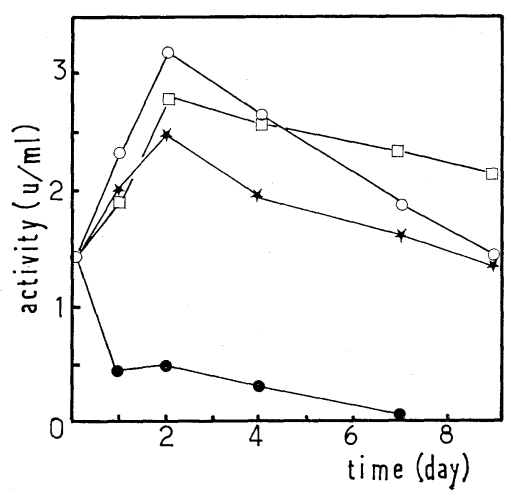

FIG. 1. Effect of Glycerol on Storage Stability of Formaldehyde Dehydrogenase.

The pure enzyme was dissolved in $5 \mathrm{~mm} \mathrm{KPB,} \mathrm{pH} 7.5$, containing $30 \mathrm{mM} \beta$-mercaptoethanol: (๑) no glycerol; (○) $5 \%$ glycerol; ( $\star$ ) $10 \%$ glycerol and $(\square) 50 \%$ glycerol. Temperature, $4^{\circ} \mathrm{C}$.

tion did not increase the stability.

\section{Effect of temperature on enzyme activity}

In our assay conditions the activity of the enzyme was maximum at a temperature of $47^{\circ} \mathrm{C}$ as shown in Fig. 2A. The profile is also given for comparison for the formaldehyde dehydrogenase of Kloeckera ${ }^{3)}$ and Candida boidinii. ${ }^{4)}$ Both enzymes showed lower optimal temperatures of 28 and $35^{\circ} \mathrm{C}$. A low activation energy of $3.2 \mathrm{kcal} / \mathrm{mol}$ was calculated from the Arrhénius plot (Fig. 2B). As expected from the optimum temperature experiment the enzyme from $P$. pastoris showed a higher thermal stability than the formaldehyde dehydrogenase from Kloeckera and $C$. boidini. A half inactivating temperature of $52^{\circ} \mathrm{C}$ was observed (Fig. $2 \mathrm{C}$ ) for the $P$. pastoris enzyme compared to $35^{\circ} \mathrm{C}$ for Kloeckera and $52^{\circ} \mathrm{C}$ for C. boidini.

\section{Effect of $p H$ on enzyme activity}

The activity was assayed in the standard conditions with $100 \mathrm{~mm} \mathrm{KBP}$ adjusted to the desired $\mathrm{pH}$. Figure 3 shows the variation of stability and activity of the enzyme with $\mathrm{pH}$. Formaldehyde dehydrogenase was not stable at pHs below 6.5 but showed higher stability on the alkaline side since it lost $50 \%$ of its activity after $10 \mathrm{~min}$ at $\mathrm{pH} 9.4$.

From the $\mathrm{pH}$ activity profile an optimum value of 7.9 was found and a loss of activity of $50 \%$ was observed at $\mathrm{pH} 6.4$ and 9.3. These values are very close to the ones observed in the stability curve since $50 \%$ inactivation occurred at pH 6.1 and 9.4. Then enzyme inactiva-
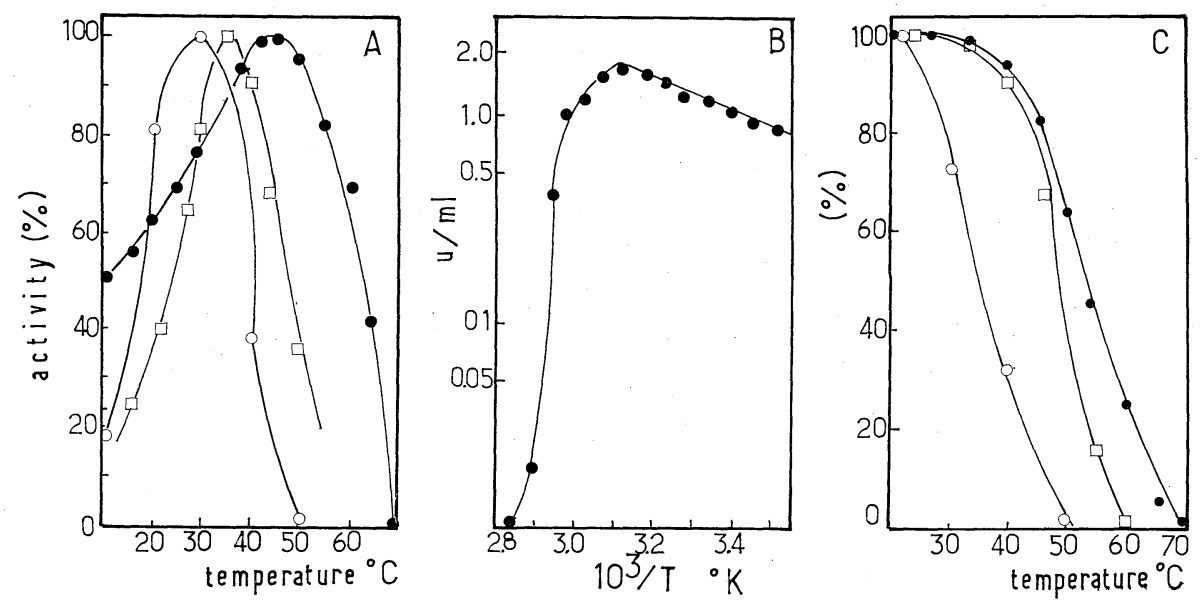

FIG. 2. Effect of Temperature on the Activity of Formaldehyde Dehydrogenase.

A) Activity temperature profiles.

B) Arrhenius plot of data presented in A.

C) Stability against temperature. The enzyme solution was incubated for $10 \mathrm{~min}$ at different temperatures and the remaining activity was assayed at $37^{\circ} \mathrm{C}$ under the standard conditions: (৩) P. pastoris IFP 206 enzyme (this work), (○) Kloeckera ${ }^{3)}$ and $C$. boidinii ${ }^{4)}$ ( $\square$ ). 


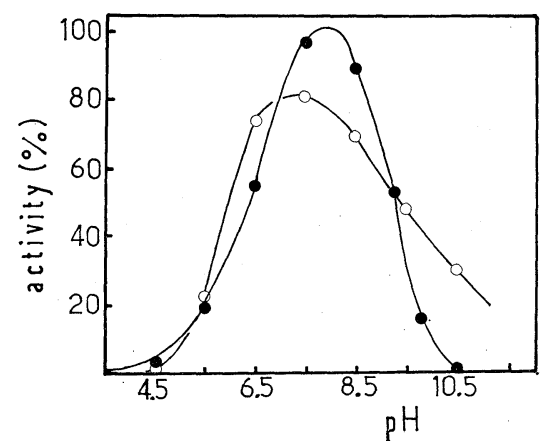

FIG. 3. Effect of pH on the Activity of Formaldehyde Dehydrogenase.

$(\bullet)$ Activity was assayed in $100 \mathrm{~mm}$ KPB adjusted to the desired $\mathrm{pH} .(\mathrm{O})$ Stability curve: Enzyme samples were incubated for $10 \mathrm{~min}$ at $37^{\circ} \mathrm{C}$ in $150 \mathrm{~mm} \mathrm{KPB}$ at different $\mathrm{pHs}$ and the remaining activity was assayed under the standard conditions ( $\mathrm{pH} 7.5$ ). In that case, $100 \%$ was assigned to the non incubated enzyme.

tion was the main reason for the observed $\mathrm{pH}$ activity profile.

\section{Substrate kinetics}

The oxidation of formaldehyde by the $P$. pastoris formaldehyde dehydrogenase followed Michaelis-Menten kinetics as shown in Fig. 4. This result is not unexpected for formaldehyde and $\mathrm{NAD}^{+}$which are known as true substrates for the enzyme. The LineweaverBurk plot allowed us to calculate the Michaelis and catalytic constants shown in Table III. It is more surprising to observe MichaelisMenten kinetics for glutathione which formed

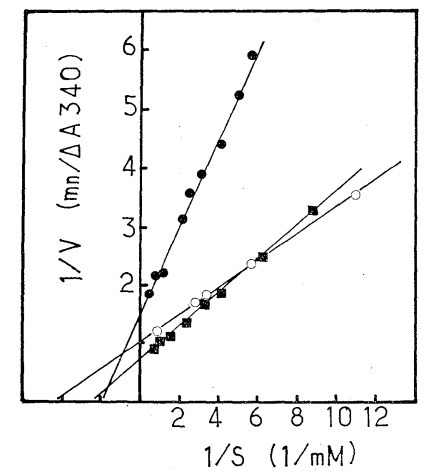

Fis. 4. Effect of Substrate Concentration on Activity of Formaldehyde Dehydrogenase.

Activity was assayed under the standard conditions except that the formaldehyde (1) or $\mathrm{NAD}^{+}(O)$ or glutathione $(\bullet)$ concentration was varied.
Table III. Kinetic Constants of Formaldehyde DeHYDRogenase OF P. pastoris

\begin{tabular}{lcc}
\hline Substrate & $\begin{array}{c}\text { Michaelis } \\
\text { constant } \\
\text { Km }(\mathrm{mM})\end{array}$ & $\begin{array}{c}\text { Catalytic } \\
\text { constant } \\
\text { kcat }\left(\min ^{-1}\right)\end{array}$ \\
\hline Formaldehyde & 0.43 & 16 \\
NAD $^{+}$ & 0.24 & 19 \\
Glutathione & 0.48 & 14 \\
\hline
\end{tabular}

spontaneously the hemimercaptal $S$-hydroxymethylglutathione (S-HMG) with formaldehyde. Several authors ${ }^{9,10}$ postulated that SHMG was the true substrate of the enzyme. Using the dissociation constant of S-HMG determined by Uotila and Koivusalo ${ }^{9)}(k d=$ $1.5 \mathrm{~mm}$ at $\mathrm{pH} 8.0$ ) it was possible to calculate the exact concentration of S-HMG in the experiments of Fig. 4 and to plot them as $1 / v$ versus $1 /[\mathrm{S}-\mathrm{HMG}]$. A Michaelis constant of $0.26 \mathrm{~mm}$ was estimated with the same order of magnitude as the apparent constant found for formaldehyde and glutathione. This kind of experiment, however, did not give any evidence that $\mathrm{S}-\mathrm{HMG}$ is (or is not) the true substrate of the enzyme.

\section{Effect of inhibitors on enzyme activity}

The results are shown in Table IV. The enzyme activity was strongly inhibited by cadmium, mercury and copper ions and to a lesser extent by zinc, manganese and nitrous ions.

TABLE IV. INHIBITORS OF THE ENZYME Activity

Activity was measured under the standard conditions in the presence of each inhibitor at the concentration of $1 \mathrm{~mm}$.

\begin{tabular}{lc}
\hline Inhibitor & Inhibition $(\%)$ \\
\hline $\mathrm{Mg}^{+2}$ & 4 \\
$\mathrm{Ca}^{+2}$ & 0 \\
$\mathrm{Mn}^{+2}$ & 9 \\
$\mathrm{Zn}^{+2}$ & 28 \\
$\mathrm{Cd}^{+2}$ & 100 \\
$\mathrm{Cu}^{+2}$ & 76 \\
$\mathrm{Hg}^{+2}$ & 90 \\
$\mathrm{NO}^{-3}$ & 0 \\
$\mathrm{NO}^{-2}$ & 14 \\
$\mathrm{CN}^{-}$ & 48 \\
EDTA & 12 \\
Citrate & 24 \\
\hline
\end{tabular}


Cyanide was also inhibitory like EDTA and citrate. Other ions showed little or no inhibition. Product inhibition studies indicated that $\mathrm{NADH}$ is a competitive inhibitor $(\mathrm{Ki}=$ $0,014 \mathrm{~mm}$ ). This inhibition is the same order as the one reported for the $C$. boidinii enzyme $(K i=0.020 \mathrm{~mm})$ by Kato et al. $\left.{ }^{11}\right)$

\section{Product identification}

Since S-HMG is a possible substrate either formate or $S$-formylglutathione (S-FG) are expected as products of the reaction. The formation of S-FG could be followed spectrophotometrically according to Uotila and Koivusalo. ${ }^{9}$ As seen in Fig. 5 the absorption at $240 \mathrm{~nm}$ of a reaction mixture under the standard conditions increased with time indicating the formation of S-FG. No increase was observed when glutathione was omitted from the reaction mixture. Addition of a small

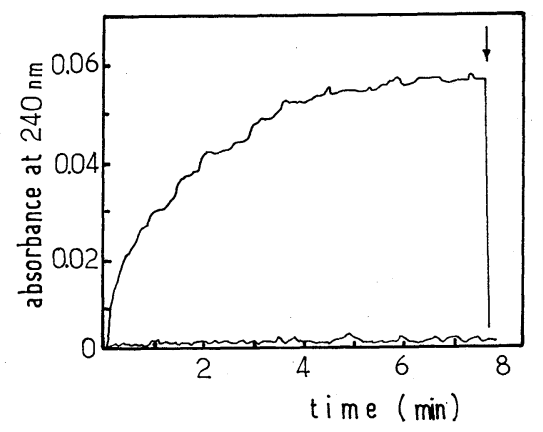

FIG. 5. Formation of $S$-Formylglutathione.

The enzyme was assayed under the standard conditions and the absorption at $240 \mathrm{~nm}$ was followed. The arrow indicates the addition of $10 \mu 1$ of cell free extract with hydrolase activity. amount $(10 \mu \mathrm{l})$ of cell free extract (arrow on Fig. 5) lead to instantaneous disappearance of the S-FG strongly suggesting the presence of a $S$-formylglutathione hydrolase (EC 3.1.2.12). ${ }^{4}$ Pure preparations of formate dehydrogenase (EC 1.2.1.2) from P. pastoris showed no hydrolase activity (A. Louktibi, unpublished results). Then it seems likely that cell free extracts of $P$. pastoris contain a S-FG hydrolase activity non-associated with the formate dehydrogenase activity as reported in Hansenula polymorpha. ${ }^{5}$

\section{DISCUSSION}

From the present results the yeast $P$. pastoris IFP 206 oxidized formaldehyde to formate according to the pathway represented in Fig. 6 . As a first step formaldehyde spontaneously forms $S$-hydroxymethylglutathione by condensation with reduced glutathione, and SHMG is oxidized by a NAD ${ }^{+}$dependent formaldehyde dehydrogenase leading to $S$ formylglutathione which is converted to formate and glutathione by a hydrolase. The hydrolytic activity was not found in purified preparations of formate dehydrogenase suggesting that two different enzymes were present like in C. boidini $^{12)}$ and Kloeckera. ${ }^{13)}$

The enzyme formaldehyde dehydrogenase was prepared in a homogeneous state and stabilized during the purification by addition of $\beta$ mercaptoethanol ${ }^{4)}$ and glycerol in all the buffers used. The properties of the enzymes from $P$. pastoris, C. boidini, Kloeckera sp. and human liver are compared in Table V.

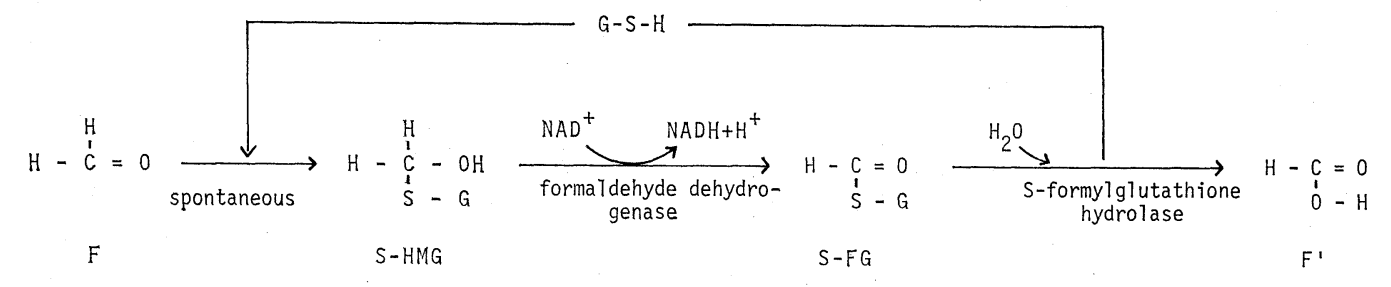

$F=$ formaldehyde $; S-H M G=S$-hydroxymethylglutathione : $S-F G=S$-formylglutathione $; F^{\prime}=$ formate ; G-S-H = reduced glutathione.

Fig. 6. Pathway of Formaldehyde Oxidation to Formate in P. pastoris. 
Table V. Comparison of Structural and Enzymatic Properties of FormaldeHyde DEHYDROGENASES

\begin{tabular}{|c|c|c|c|c|}
\hline & $\begin{array}{l}P_{\text {p pastoris }} \\
\text { IFP } 206\end{array}$ & C. boidini & Kloeckera sp. & Human liver \\
\hline Molecular weight $(\mathrm{g})$ & 84,000 & 80,000 & - & 81,400 \\
\hline Molecular weight of subunits (g) & 39,000 & 40,000 & - & 39,500 \\
\hline$S_{25, \mathrm{w}}(\mathrm{S})$ & 5.2 & 4.9 & - & - \\
\hline$\left(\mathrm{cm}^{3} / \mathrm{g}\right)$ & 0.765 & 0.749 & - & - \\
\hline$A_{1 \mathrm{~cm}}^{1 \%}$ & 10.4 & 10.0 & - & - \\
\hline Optimum temperature $\left({ }^{\circ} \mathrm{C}\right)$ & 47 & 35 & 30 & - \\
\hline Thermal stability $\left({ }^{\circ} \mathrm{C}\right)^{a}$ & 57 & 52 & 35 & - \\
\hline Activation energy ( $\mathrm{kcal} / \mathrm{mol})$ & 3.2 & $13.0^{b}$ & $17.6^{b}$ & - \\
\hline Optimum pH & 7.9 & 8.5 & 8.0 & 8.2 \\
\hline \multicolumn{5}{|l|}{ Michaelis constant (mM) } \\
\hline Formaldehyde & 0.43 & 0.25 & 0.29 & $0.009 \sim 0.0047$ \\
\hline $\mathrm{NAD}^{+}$ & 0.24 & 0.09 & 0.02 & 0.009 \\
\hline Glutathione & 0.48 & 0.13 & - & 0.008 \\
\hline$S$-hydroxymethyl glutathione & 0.26 & - & - & 0.0065 \\
\hline Reference & This work & Schütte et $a l .{ }^{4)}$ & Kato et al..$^{3)}$ & $\begin{array}{l}\text { Uotila and } \\
\text { Koivusalo }^{9)}\end{array}$ \\
\hline
\end{tabular}

a Temperature of incubation resulting in $50 \%$ loss of activity.

$b$ Estimated from the data of Schütte et al. ${ }^{4)}$ and Kato et al. ${ }^{3)}$

The $P$. pastoris enzyme is composed of two identical subunits of a molecular weight of 39,000 and is $\mathrm{NAD}^{+}$and glutathione dependent. The values of the coefficient of sedimentation, partial specific volume and absorption coefficient are very close to the ones of the $C$. boidini enzyme. The optimum temperature is much higher for the $P$. pastoris enzyme and the activation energy is low.

All the 12 cysteine residues of the molecule were in the reduced form in the enzyme preparation. Whether this is an artefact of purification due to the high concentration of $\beta$ mercaptoethanol used or the true value for the native enzyme is not known. Elimination of $\beta$ mercaptoethanol by dialysis did not change the enzymatic activity and cell free extracts prepared with or without $\beta$-mercaptoethanol showed the same activity.

In the presence of $\mathrm{NAD}^{+}$the number of titrable -SH groups rose from 6.3 to 12.5 in non-denaturing conditions. This could be the result of an important conformational change of the molecule unmasking 6-SH groups or of a difference in subunit interactions where - $\mathrm{SH}$ groups are known to be very important.

The kinetic properties of the $P$. pastoris enzyme are characterized by a low affinity for the cofactor $\mathrm{NAD}^{+}$compared to the yeast and human enzymes. The affinities for formaldehyde and glutathione are similar to the two other yeast enzymes but much lower than for the human enzyme.

It is generally admitted that the true substrate of formaldehyde dehydrogenase is S-HMG taking into account the absolute requirement for reduced glutathione and the low $\mathrm{km}$ found for S-HMG. This situation is likely to occur in $P$. pastoris. However it cannot be excluded that formaldehyde is the true substrate, glutathione being an enzyme activator or a third substrate of the dehydrogenase.

In conclusion formaldehyde dehydrogenase from $P$. pastoris closely ressembled the $C$. boidini and Kloeckera enzymes as already demonstrated for the alcohol oxidase of these strains. ${ }^{2)}$ Then the oxidation of methanol by methylotrophic yeasts not only follows the same reaction scheme but also utilizes very closely related enzymes.

Acknowledgments. The authors wish to thank Dr. Ballerini, Institut Français du Pétrole, for providing the cells of $P$. pastoris and for his interest during this work. 


\section{REFERENCES}

1) D. Ballerini, Revue de l'Institut Français du Petrole, 33, 111 (1978).

2) R. Couderc and J. Baratti, Agric. Biol. Chem., 44, 2279 (1980).

3) N. Kato, T. Tamaoki, Y. Tani and K. Ogata, Agric. Biol. Chem., 36, 2411 (1972).

4) H. Schütte, J. Flossdorf, H. Sahm and M. R. Kula, Eur. J. Biochem., 62, 151 (1976).

5) J. P. Van Dijken, G. J. Oostra-Demkes, R. Otto and W. Harder, Arch. Microbiol., 111, 77 (1976).

6) O. H. Lowry, N. J. Rosebrough, A. L. Farr and R. J. Randall, J. Biol. Chem., 193, 265 (1951).
7) J. Babul and E. Stellwagen, Anal. Biochem., 28216 (1969).

8) M. Delaage, Biochim. Biophys. Acta, 168, 573 (1968).

9) L. Uotila, M. Koivusalo, J. Biol. Chem., 249, 7653 (1974).

10) H. Sahm, Adv. Biochem. Eng., 6, 77 (1977).

11) N. Kato, H. Sahm and F. Wagner, Biochim. Biophys. Acta, 566, 12 (1979).

12) I. Neben, H. Sahm and M. R. Kula, Biochim. Biophys. Acta, 614, 81 (1980).

13) N. Kato, C. Sakazawa, T. Nishizawa, Y. Tani and H. Yamada, Biochim. Biophys. Acta, 611, 323 (1980). 